\title{
MITRAL RESTENOSIS
}

\author{
BY \\ G. C. PATTERSON AND J. R. MARSHALL \\ From the Royal Victoria Hospital, Belfast \\ Received May 1, 1958
}

There is still considerable difference of opinion regarding the incidence of restenosis following adequate mitral valvotomy. Glover (1955) in a study of patients five years after this operation stated that restenosis of the mitral valve was unlikely to occur. This view is not now accepted. Muehsam and Auerbach (1957) observed tight mitral stenosis at autopsy four years following adequate mitral valvotomy. Belcher (1958) in a review of previous reports found seven cases of restenosis and contributed a further four.

The object of this communication is to report seven patients showing restenosis of the mitral valve confirmed at a second operation. The seven cases occurred following four hundred operations performed in this hospital before the end of 1956 (Pantridge et al., 1953; Marshall and Pantridge, 1957).

Since restenosis of the mitral valve may easily be confused with inadequate division of the commissures, it was considered essential that the surgeon's report at the initial operation should indicate complete division of one or both commissures and that good clinical improvement should follow the operation. Care was taken to exclude causes other than mitral obstruction for the recurrence of symptoms. Finally, it was required that the second operation show tight or very tight stenosis with fusion of the previously divided commissure or commissures.

The seven patients who fulfilled these conditions were prior to the initial operation severely incapacitated by mitral stenosis. One patient had an associated minimal degree of aortic regurgitation. The state of the mitral valve as estimated by the surgeon at the first operation and the degree of division obtained are shown in Table I. The stenosis was classified as very tight where it was found impossible to introduce the finger tip into the valve orifice and as tight where the orifice would just admit the tip of the finger.

Following the initial valvotomy, improvement was marked in all patients, allowing a return to normal activity. They were able to carry on with their previous occupations and were virtually symptomless.

Symptoms recurred at intervals ranging from 8 to 41 months. There was a rapidly progressive decrease in exercise tolerance for which no cause other than mitral stenosis was found. A second operation became imperative in 5 to 36 months after the onset of symptoms. Cardiac catheterization prior to the second operation in each case showed a rise in pulmonary wedge pressure at rest and a further rise on exercise.

With one exception the second operation was performed by the surgeon who did the initial valvotomy. Tight or very tight stenosis was present (Table I). The degree of splitting obtained, while very good in one patient, was' in general not so satisfactory as at the initial valvotomy. Improvement has been obtained in six patients, but one failed to improve and died in congestive heart failure three months after operation.

Rheumatic activity is thought to be responsible for restenosis of the mitral valve. However, at the time of both operations the seven patients reported here were free from clinical evidence of 
TABLE I

Clinical Pre-Operative and Post-Operative Data in Seven Patients with Mitral Restenosis

\begin{tabular}{|c|c|c|c|c|c|c|c|}
\hline \multirow{2}{*}{ Patient } & \multirow{2}{*}{ Age } & \multicolumn{2}{|c|}{ First valvotomy } & \multirow{2}{*}{$\begin{array}{l}\text { Interval } \\
\text { before } \\
\text { recurrence } \\
\text { of } \\
\text { symptoms }\end{array}$} & \multirow{2}{*}{$\begin{array}{l}\text { Duration } \\
\text { of } \\
\text { symptoms } \\
\text { before } \\
\text { second } \\
\text { operation }\end{array}$} & \multicolumn{2}{|c|}{ Second valvotomy } \\
\hline & & $\begin{array}{l}\text { Pre-operative } \\
\text { condition } \\
\text { of valve }\end{array}$ & $\begin{array}{l}\text { Splitting } \\
\text { obtained }\end{array}$ & & & $\begin{array}{l}\text { Pre-operative } \\
\text { condition } \\
\text { of valve }\end{array}$ & $\begin{array}{l}\text { Splitting } \\
\text { obtained }\end{array}$ \\
\hline 1 & 41 & Tight & $\begin{array}{l}\text { MC complete } \\
\text { LC half }\end{array}$ & 23 months & 20 months & Tight & $\begin{array}{l}\text { MC nil } \\
\text { LC complete }\end{array}$ \\
\hline 2 & 39 & Tight & $\begin{array}{l}\text { MC nil } \\
\text { LC complete }\end{array}$ & 24 months & 36 months & Tight & $\begin{array}{l}\text { MC nil } \\
\text { LC complete }\end{array}$ \\
\hline 3 & 38 & Tight & $\begin{array}{l}\text { MC complete } \\
\text { LC complete }\end{array}$ & 8 months & 7 months & Tight & $\begin{array}{l}\text { MC nil } \\
\text { LC complete }\end{array}$ \\
\hline 4 & 23 & Tight & $\begin{array}{l}\text { MC complete } \\
\text { LC nil }\end{array}$ & 39 months & 19 months & Very tight & $\begin{array}{l}\text { MC very little } \\
\text { LC very little }\end{array}$ \\
\hline 5 & 28 & Tight & $\begin{array}{l}\text { MC complete } \\
\text { LC half }\end{array}$ & 30 months & 5 months & Tight & $\begin{array}{l}\text { MC complete } \\
\text { LC nil }\end{array}$ \\
\hline 6 & 24 & Very tight & $\begin{array}{l}\text { MC complete } \\
\text { LC complete }\end{array}$ & 27 months & 15 months & Tight & $\begin{array}{l}\text { MC half } \\
\text { LC complete }\end{array}$ \\
\hline 7 & 38 & Tight & $\begin{array}{l}\text { MC nil } \\
\text { LC complete }\end{array}$ & 41 months & 25 months & Very tight & $\begin{array}{l}\text { MC very little } \\
\text { LC very little }\end{array}$ \\
\hline
\end{tabular}

$$
\mathrm{MC}=\text { medial commissure. } \quad \mathrm{LC}=\text { lateral commissure. }
$$

rheumatic activity and had normal erythrocyte sedimentation rates. In five instances the auricular biopsy obtained at the time of the first operation was submitted for histological report. Aschoff bodies were found in only one (Case 4).

At routine reviews after operation a careful enquiry was made regarding joint pains, and sedimentation rates were recorded. One patient (Case 3) showed a raised erythrocyte sedimentation rate $(24 \mathrm{~mm}$. in one hour Westergren) on an isolated occasion, thirteen months after the initial operation. Another had an episode of joint pains with a raised erythrocyte sedimentation rate two months after operation. The remaining five patients never at any time during the period of observation before and after operation had clinical evidence suggesting rheumatic activity.

The age of the seven patients was representative of the series of four hundred among which they occurred.

\section{Discussion}

Symptoms attributable to restenosis appeared at intervals of 8 to 41 months following operation and it is probable that further cases will occur. Wood (1954) has pointed out that the true incidence of restenosis will not be known until patients have been studied for a much longer period after mitral valvotomy than is yet possible. However, the condition is sufficiently common to justify careful investigation of patients who after operation show deterioration without obvious cause.

The rtiology of the restenosis is not entirely clear. Active rheumatism is a possibility. A history of a fresh attack of rheumatism in the interval between the original valvotomy and the recurrence of symptoms has been given in many of the reported cases (McKusick, 1955; Glenn and Dineen, 1956; Donzelot et al., 1953; Dussailant et al., 1954; Morino, 1955; and Belcher, 1958). However, Muehsam and Auerbach (1957) in an examination of one case at necropsy were unable to find histological evidence of recent rheumatic activity either in the myocardium or in the region of the valve despite a careful search. Five of the seven patients had auricular biopsies taken at the initial operation: only one showed the presence of Aschoff bodies. Biopsy material was available from 220 of the initial 400 patients submitted to mitral valvotomy in this hospital: sixty-two $(28 \%)$ showed Aschoff nodules in the auricular myocardium.

The absence of Aschoff bodies in the biopsy of four of the patients reported here does not exclude rheumatic activity. It does, however, indicate that in so far as rheumatic activity can be detected 
those patients were free from it at the time of the initial operation. It has been noted that no clinical evidence of rheumatic activity in these four patients was found in the period of observation before and after the two operations.

The findings reported here would suggest that active rheumatism may not be the only ætiological factor concerned in mitral restenosis.

\section{SUMMARY}

Seven cases of restenosis of the mitral valve following adequate mitral valvotomy are reported. A second operation was followed by improvement in six of the patients, but one failed to improve and died three months after operation. In four cases no evidence of rheumatic activity was found during the period of observation before and after operation. It is suggested that active rheumatism may not be the only ætiological factor concerned in mitral restenosis.

The operations were performed by Mr. J. A. W. Bingham, Mr. T. B. Smiley, and Mr. H. M. Stevenson.

We wish to thank Dr. J. F. Pantridge for permission to study these patients who were under his care and for his advice and criticism.

\section{REFERENCES}

Belcher, J. R. (1958). Brit. Heart J., 20, 76.

Donzelot, E., Dubost, C., de Balzac, R. H., Metianu, C., and Guillemot, R. (1953). Arch. Mal., Caur, $46,300$.

Dussailant, G., Allamand, J., Sunkel, W., Del Valle, A., and Carrasco, R. (1954). Rev. Med., Chile, 82, 92.

Glenn, F., and Dineen, P. (1956). Ann. Surg., 143, 405.

Glover, R. P., Davilla, J. C., O’Neill, T. J. E., and Janton, O. H. (1955). Circulation, 11, 14.

McKusick, V. A. (1955). Arch. intern Med., 95, 557.

Marshall, R. J., and Pantridge, J. F. (1957). Ulster med. J., 27, 155.

Morino, F. (1955). Minerva Med. Tor., 36, 1033.

Muehsam, G. E., and Auerbach, O. (1957). Ann. intern Med., 46, 1177.

Pantridge, J. F., Smiley, T. B., and Henry, E. W. (1953). Ulster med. J., 22, 126.

Wood, P. (1954). Brit. med. J., 1, 1113. 